УДК 377.091.12:005.963

\title{
СУЧАСНІ ПРОБЛЕМИ РОЗВИТКУ ПРОФЕСІЙНОЇ КОМПЕТЕНТНОСТІ МЕТОДИСТІВ ПРОФЕСІЙНО-ТЕХНІЧНИХ НАВЧАЛЬНИХ ЗАКЛАДІВ У МІЖКУРСОВИЙ ПЕРІОД ПІВИЩЕННЯ КВАЛІФІКАЦІї
}

\author{
Євдокія Горбан, \\ аспірант Інституту професійно-технічної освіти НАПН України
}

КЛЮЧОВІ
СЛОВА:
професійна
компетентність,
педагогічний
працівник,
методист,
науково-методична
робота,
безперервна освіта,
міжкурсовий період,
удосконалення
фахової
майстерності,
підвищення
кваліфікації

Реферат
У статті зосереджено увагу на необхідності теоретичного обгрунтування, розробки й експериментальної перевірки технології розвитку професійної компетентності методистів професійно-технічних навчальних закладів у міжкурсовий період підвищення кваліфікації, що включає ціннісно-мотиваційний, інформаційно-когнітивний, професійнодіяльнісний і рефлексивно-оцінний етапи реалізації та ставить за мету безперервне професійно-педагогічне вдосконалення, самовдосконалення i саморозвиток, оволодіння інноваційними компетентностями професійної освіти, опанування коучинговими програмами стажування та наставництва.

Охарактеризовано суперечності, що виникають внаслідок системного впровадження нової техніки та передових технологій, що вимагають постійної готовності працівників до змін характеру праці й самих професій, зростання загальноосвітнього та технічного рівнів, коли об'єктивно виникає потреба у всебічному гармонійному розвитку всіх суб'єктів, котрі беруть участь у виробництв. За таких умов педагогічні працівники повинні бути налаштовані на постійне оновлення своїх знань, професійних умінь i навичок, збагачення досвіду пізнавальної практичної діяльності, що підкріплюється відповідними ціннісними орієнтаціями. Наведено структуру педагогічної компетентності, розкрито суть професійної компетентності.

На основі узагальнення наукових досліджень встановлено, що професійна компетентність розглядається як професійна підготовка i здатність педагогічних працівників (методистів) до виконання завдань і обов'язків діяльності, міра та основний критерій їх відповідності вимогам професійної діяльності, що складається з таких компонентів: знання, уміння, навички, професійна позиція, індивідуальні психологічні особливості людини та акмеологічні чинники (цінності та потреба в саморозвитку).

Зосереджено увагу на реалізації творчого потенціалу методистів професійно-технічних навчальних закладів як суб'єктів професійної діяльності у взаємодії з іншими суб'єктами навчально-виховного процесу через розвиток професійної компетентності, що дає їм змогу успішно виконувати різноманітні види професійної діяльності, синтезувати широкий спектр знань та практичних дій, відображати ступінь сформованості професійної культури фахівців і визначати результати їх роботи.

Охарактеризовано роль методистів професійно-технічних навчальних закладів в організації науково-методичної роботи 3 педагогічними працівниками (викладачами, майстрами виробничого навчання). Розкрито проблеми розвитку професійної компетентності методистів професійнотехнічних навчальних закладів у міжкурсовий період підвищення кваліфікації.

Постановка проблеми. В умовах змісту модернізації професійної (професійнотехнічної освіти) підвищуються вимоги до професіоналізму педагогічних працівників професійно-технічних навчальних закладів (ПТНЗ), здатних формувати в учнів високий рівень професійної компетентності. Йдеться про професійну компетентність викладачів і майстрів виробничого навчання, які переважно $\epsilon$ випускниками галузевих вищих навчальних закладів, а, отже, потребують значної уваги відповідних методичних служб 
Євдокія Горбан. Сучасні проблеми розвитку професійної компетентності методистів професійно-технічних навчальних закладів у міжкурсовий період підвищення кваліфікації

ПТНЗ. 3 огляду на це, зростає роль методистів у наданні допомоги педагогам щодо реалізації актуальних завдань особистісного розвитку, вдосконалення й підвищення професійної майстерності та рівня психологічної підготовки.

У системі методичної роботи навчальних закладів чільне місце належить методистам. Водночас, притаманний їм рівень професійної компетентності є недостатнім для повноцінного виконання покладених на них завдань. Тому постає необхідність теоретичного обгрунтування, розробки й експериментальної перевірки технології розвитку професійної компетентності методистів ПТНЗ у міжкурсовий період підвищення кваліфікації, що включає ціннісно-мотиваційний, інформаційнокогнітивний, професійно-діяльнісний i рефлексивно-оцінний етапи іiі реалізації та ставить за мету безперервне професійнопедагогічне вдосконалення, самовдосконалення й саморозвиток, оволодіння інноваційними компетентностями, опанування коучинговими програмами стажування та наставництва.

Аналіз останніх досліджень і публікацій показав, що проблему компетентнісного підходу у професійній освіті досліджували у своїх наукових працях І.Зязюн, Н.Кузьміна, В.Луговий, Л.Петренко, В.Радкевич, Л.Хоружа, А.Хуторський, В.Ягупов та ін. Методичні основи вдосконалення педагогічної майстерності вивчали: О.Дубасенюк, А.Каленський, М.Михнюк, Н.Морєва, О.Отич, Л.Хомич та ін. Інноваційну діяльність педагогів, упровадження сучасних технологій навчання розглядали: М.Артюшина, Н.Брюханова, Л.Сршова, І.Зимня, А.Литвин, П.Лузан, О.Пєхота, Г.Романова, М.Сибірська, С.Сисоєва, О.Спірін, О.Щербак та ін. Однак поза увагою вчених залишилися сучасні проблеми розвитку професійної компетентності методистів ПТНЗ у міжкурсовий період підвищення кваліфікації.

Зазначене зумовило виникнення низки суперечностей: між потребами українського суспільства в професійно розвинених методичних працівниках та недостатнім рівнем забезпечення у ПТНЗ відповідних для цього педагогічних умов; між істотним зростанням вимог педагогічної практики до якості професійної діяльності методистів та недостатнім обгрунтуванням моделі, котра забезпечувала б розвиток їхньої професійної компетентності в міжкурсовий період підвищення кваліфікації; між необхідністю поетапного розвитку професійної компетентності методистів та невідповідністю наявних у ПТНЗ технологій, які б цьому сприяли.

Мета статті полягає в обгрунтуванні сучасних проблем розвитку професійної компетентності методистів ПТНЗ у міжкурсовий період підвищення кваліфікації.

Виклад основного матеріалу. У сучасних умовах реалізації Національної стратегії розвитку освіти в Україні на 20122021 роки, яка визначає основні напрями, пріоритети, завдання державної політики в галузі освіти, кадрову й соціальну політику, спрямовану на підвищення якості й конкурентоспроможності освіти, вирішення стратегічних завдань, що стоять перед національною системою освіти в нових економічних i соціокультурних умовах, діяльність методичної служби ПТНЗ набуває важливого значення.

Особливу роль у реформуванні освіти відіграє вдосконалення науково-методичної роботи шляхом формування інноваційного освітнього середовища, реалізації особистісно орієнтованого, індивідуального та диференційованого підходу до підвищення їхньої професійної компетентності. Методична робота визначається в наукових джерелах як цілісна, заснована на досягненнях науки, освітніх інноваціях, конкретному аналізі стану навчальновиховного процесу, система діагностичної, пошукової, аналітичної, інформаційної, організаційної діяльності та заходів, спрямованих на всебічне підвищення професійної майстерності кожного педагога, розвиток творчого потенціалу педагогічного колективу навчального закладу в цілому та вдосконалення якості навчально-виховного процесу [2].

У структурі педагогічної компетентності (Т.Браже, С.Вершловський, Ю.Кулюткін, Г.Суховська) виділяють такі компоненти: професійно-освітній (професійні теоретичні знання та уміння); професійно-діяльнісний (здатність застосовувати отримані знання та уміння на практиці); професійно- 
особистісний (особистісні якості вчителя професійна спрямованість, гуманізм, педагогічне мислення, рефлексивні процеси тощо).

Поняття «професійна компетентність» увійшло до термінології у 1980-х рр. Російський учений А.Хуторський ввів поняття «ключові компетентності». Зміст професійної компетентності полягає в поєднанні предмета, методик його викладання, педагогіки і психології, уміння синтезувати знання з різних наук і вирішувати педагогічні завдання, аналізувати педагогічні ситуації.

Професійна компетентність $є$ підвалиною педагогічної майстерності. На думку І.Зязюна, професійна компетентність входить у системне поняття «педагогічна майстерність». Як стверджував учений, складність набуття професійної компетентності полягає в тому, що професійне знання має формуватися на всіх рівнях: методологічному, теоретичному, методичному, технологічному[3]. Г.Бєлєнька розглядає професійну компетентність як особистісний інтеграл, структурними компонентами якого є мотиви діяльності, системні знання, фахові уміння та професійно значущі якості особистості [1].

Аналіз наукових публікацій останніх років свідчить про те, що поруч із поняттям «професійно-педагогічна компетентність» (загальна властивість особистості як професіонала) вчені використовують і таке поняття як «компетенція» (коло повноважень установи чи особи) [6].

На основі результатів проведеного дослідження можемо стверджувати, що професійною компетентністю називають здатність педагогічних працівників до виконання завдань і обов'язків діяльності, міра та основний критерій їх відповідності вимогам професійної діяльності. До компонентів їхньої професійної компетентності відносять: знання, уміння, навички, професійну позицію, індивідуальні психологічні особливості людини та акмеологічні чинники (цінності та потреба в саморозвитку).

Професійно-технічний навчальний заклад відчуває потребу в методистах із чітко сформованою професійною компетентністю, які постійно прагнуть: до творчого пошуку; мають навички дослідницько- експериментальної діяльності, виявлення, вивчення, узагальнення, поширення, пропагування, впровадження педагогічного досвіду; високий рівень інформаційної культури; уміють інтерпретувати новий зміст освіти в методику навчання і виховання; здатні здійснювати аналіз результатів професійної діяльності як своєї власної, так і педагогічного й учнівського колективів.

Пріоритетним завданням методичної служби ПТНЗ нині $\epsilon$ пошук шляхів підвищення якості безперервного навчання педагогічних працівників, у тому числі й методистів, розвиток педагогічної майстерності, формування навичок науководослідницької роботи.

Найважливішою умовою успішної діяльності методистів ПТНЗ, творчого підходу до реалізації модернізації методичних функцій $\epsilon$ наявність професійної компетентності й професіоналізму [4].

Згідно із сучасними вимогами, методисти ПТНЗ у межах професійної компетентності мають:

- досконало володіти комунікативними та організаційними здібностями, методами науково-дослідної та експериментальної роботи;

- уміти розробляти пропозиції щодо підвищення ефективності навчальновиробничого та виховного процесу, створювати і працювати з творчими групами 3 розробки інноваційних соціальнопедагогічних технологій, цільових комплексних та інших освітніх програм;

- запроваджувати ефективні форми навчально-виробничої, виховної, суспільномасової, просвітницької роботи;

- вивчати, узагальнювати та поширювати кращий педагогічний досвід;

- розробляти власні методичні рекомендації, програми, посібники з проблем професійно-технічної освіти, підтримувати постійні зв'язки 3 методичними службами різних установ та педагогами інших типів навчальних закладів.

Виходячи із викладеного, методисти ПТНЗ мають володіти знаннями: 3 основ методичної роботи і методики педагогічних досліджень; сучасних досягнень техніки, психолого-педагогічної, методичної науки i досвіду роботи педагогічних колективів інших ПТНЗ як свого регіону, так і України; 
Євдокія Горбан. Сучасні проблеми розвитку професійної компетентності методистів професійно-технічних навчальних закладів у міжкурсовий період підвищення кваліфікації

щодо потреб і вимог до створення системи підвищення кваліфікації педагогічних кадрів тощо.

Зважаючи на те, що головним показником педагогічної майстерності $\epsilon$ рівень вивчення й запровадження досвіду інших педагогів, відпрацювання особистої концепції або авторської методики, створення нової концепції навчання, виробничої діяльності, виховання (педагогічної інновації) i дослідницький рівень педагогічної діяльності, методисти ПТНЗ мають уміти:

- вивчати й аналізувати роботу членів педагогічного колективу;

- проводити анкетування, тестування, статистичну обробку даних;

- описувати педагогічний факт або явище; книги;

готувати реферати, рецензії на статтю,

- узагальнювати досвід свій і своїх колег, готувати науково-методичну доповідь тощо;

- створювати сприятливе методичне середовище для особистісного розвитку педагога;

- оволодівати змістом сучасної освіти й тенденціями змін в освітньому просторі;

- володіти методологією організації роботи педагогічних кадрів у міжкурсовий період підвищення кваліфікації;

- проводити експертне оцінювання творчих знахідок педагогів, моделювати педагогічний досвід і узагальнювати одержані результати;

- розробляти методичні рекомендації.

Методисти ПТНЗ у своїй роботі використовують різні форми й методи діяльності, в тому числі, практичної спрямованості. Пріоритетними напрямами роботи мають бути зв'язки 3 науковими установами, вищими навчальними закладами, укладання 3 ними угод щодо спільної діяльності за визначеною проблематикою тощо. Результатом проведеної роботи має стати підготовка друкованої продукції 3 методики організації навчання, виробничої практики, виховання учнівської молоді, узагальнення кращого досвіду професійної практики .

У міжкурсовий період підвищення кваліфікації, на етапі самовдосконалення i саморозвитку, методисти закладів професійної освіти мають працювати над розвитком професійної компетентності, що включає:

- оволодіння досягненнями педагогіки i психології;

- оволодіння та впровадження в навчально-виробничий $\mathrm{i}$ виховний процес інноваційних технологій, що передбачає створення нових зразків діяльності педагогів, які сприяли б їньому професійному зростанню та виводили на принципово новий, якісний фаховий рівень;

- уміння визначати шляхи вирішення проблеми діяльності педагогічного колективу;

- перспективний досвід роботи 3 педагогічними кадрами;

- удосконалення основних вимог до розробки системи методичної роботи;

- чітке визначення шляхів організаційно-методичного забезпечення, функціонування методичної роботи в закладі.

При цьому методисти ПТНЗ мають враховувати такі компоненти:

- вивчення професійної компетентності педагогів та використання цих результатів при розробці методичної роботи, аналіз результатів методичної роботи за минулий рік;

- планування методичної роботи на рік (визначення мети та завдань, змісту та форм, часу й місця проведення, призначення керівників творчих груп тощо);

- шляхи реалізації завдань (підготовка розпорядчого документа про організацію методичної роботи, про затвердження керівників методичних комісій);

- розробка програми надання допомоги у плануванні всіх форм методичної роботи;

- визначення проблем і практичних завдань діяльності творчих груп, шкіл перспективного педагогічного досвіду тощо;

- забезпечення санітарно-гігієнічних умов, належного рівня матеріальнотехнічного стану; стимулювання

активності педагогічних кадрів;

забезпечення достатнього рівня інформаційного насичення методичних заходів;

- спрямованості методичної роботи надання адресної допомоги кожному педагогу та достатньої її гнучкості й динамізму; 
- установлення творчих зав'язків із науковими та методичними закладами, організаціями, які можуть сприяти підвищенню рівня методичної роботи закладу;

- сприяння створенню творчих лабораторій керівників творчих об'єднань, експериментальної роботи тощо;

- вивчення процесу методичної роботи та внесення в неї, за потреби, відповідних коректив;

- оцінка ефективності методичної роботи.

Розвиток професійної компетентності методистів ПТНЗ у міжатестаційний період підвищення кваліфікації може бути значно ефективнішим, якщо реалізувати такі педагогічні умови:

- формування позитивної мотивації до професійно-педагогічного вдосконалення, самовдосконалення та саморозвитку;
- навчання в регіональній Школі професійно-педагогічної майстерності;

- упровадження особистісно орієнтованої технології розвитку професійної майстерності;

- участь у професійних конкурсах, освітніх виставках, науково-практичних заходах.

Висновок. Створення належних педагогічних умов розвитку професійної компетентності методистів у міжкурсовий період підвищення кваліфікації приведе до формування атмосфери зацікавленості у підвищенні педагогічної майстерності, вдосконалення рівня методичної роботи у ПТНЗ.

Викладене матиме безпосередній уплив на якість організації навчально-виховного процесу, задовольнить ширші практичні, духовні, естетичні, моральні та інші запити педагогів, що створить умови для виникнення людських контактів та творчого спілкування, об’єднає на шляху реалізації спільної мети.

\section{Література}

1. Бєлєнька Г.В. Теоретико-методичні засади формування професійної компетентності вихователів дошкільних навчальних закладів в умовах ступеневої підготовки : автореф. дис. на здобуття наук. ступеня д-ра пед. наук : спец. 13.00.08 «Теорія і методика професійної освіти» / Г.В.Бєлєнька. - Київ, 2012. - 38 с.

2. Енциклопедія освіти / гол. ред.. академік НАН і НАПН України, Президент АПН України В.Г.Кремень. Київ, Юрінком, 2008. - 1036 c.

3. Зязюн I.А. Педагогічна майстерність : підручник / І.А.Зязюн, І.Ф.Кравченко, І.Ф.Кривоноса ін. ; за ред. І.А.Зязюна. - 2-ге вид., доповн. - Київ. Вища школа, 2004. $422 \mathrm{c}$.

4. Радкевич В.О. Компетентнісний підхід до забезпечення якості професійної освіти i навчання / В. О. Радкевич - [Електронний pecypc]. - http://lib.iitta.gov.ua/

5. Розвиток інформаційно-аналітичної компетентності педагогічних працівників ПТНЗ: теорія і практика : монографія / [B. В. Ягупов, Н. О. Величко, І. В. Гириловська, А. Г. Гуралюк, Д. О. Закатнов, Л. А. Майборода, В. В. Паржницький] ; за. наук. ред. В.В. Ягупова. - Київ : Поліграфсервіс, 2014. - 176 с.

Ягупов В.В. Методологические требования компетентносного подхода в профессиональном образовании / В.В.Ягупов // Вища освіта України : теорет. та науковометод.часопис. - 2013. - №13(50). - Додаток 1 : Педагогіка вищої школи: методологія, теорія, технології. - Т. 1. - С. 82-85. 
Євдокія Горбан. Сучасні проблеми розвитку професійної компетентності методистів професійно-технічних навчальних закладів у міжкурсовий період підвищення кваліфікації

\section{Реферат \\ Современные проблемы развития профессиональной компетентности методистов профессионально-технических учебных заведений в межкурсовой период повышения квалификации}

Евдокия Горбан, аспирант Института профессионально-технического образования НАПН Украинь

\section{КЛЮЧЕВЫЕ}

СЛОВА:

профессиональные компетентности, педагогический работник, методист, научнометодическая работа, непрерывное образование, межкурсовой период, совершенствование профессионального мастерства, повышение квалификации
В статье сосредоточено внимание на необходимости теоретического обоснования, разработки и экспериментальной проверки технологи развития профессиональной компетентности методистов профессиональнотехнических учебных заведений в межкурсовой период повышения квалификации, которая включает ценностно-мотивационный, информационно-когнитивный, профессионально-деятельностный и рефлексивно-оценочный этапы реализации, и ставит целью непрерывное профессионально-педагогическое совершенствование, самоусовершенствование и саморазвитие, овладение коучинговыми программами стажировки и наставничества. Охарактеризованы противоречия, которые возникают в результате постоянного внедрения новой техники и передовых технологий, которые требуют постоянной готовности работников к изменениям характера труда и самих профессий, роста общеобразовательного и технического уровней, когда объективно возникает потребность во всестороннем гармоничном развитии всех субъектов, которые принимают участие в производстве. При таких условиях педагогические работники должны бать настроены на постоянное обновление своих знаний, профессиональных умений и навыков, обогащение опыта познавательной практической деятельности, которая подкрепляется соответствующими ценностными ориентациями. Приведена структура педагогической компетентности, раскрыта суть профессиональной компетентности.

На основании обобщения научных исследований установлено, что профессиональная компетентность рассматривается как профессиональная подготовка и способность педагогических работников (методистов) к выполнению заданий и обязанностей деятельности, мера и основной критерий их соответствия требованиям профессиональной деятельности, которая состоит из таких компонентов: знания, умения, навыки, профессиональная позиция, индивидуальные психологические особенности человека и акмеологические факторы (ценности и потребность в саморазвитии). Сосредоточено внимание на реализации творческого потенциала методистов профессионально-технических учебных заведений как субъектов профессиональной деятельности во взаимодействии с другими субъектами учебно-воспитательного процесса через развитие профессиональной компетентности, которая дает им возможность успешно выполнять разнообразные виды профессиональной деятельности, синтезировать широкий спектр знаний и практических действий, отображать степень сформированности профессиональной культуры специалистов и определять результаты их работы. Охарактеризована роль методистов профессионально-технических учебных заведений в организации научно-методической работы с педагогическими работниками (преподавателями, мастерами производственного обучения). Раскрыты проблемы развития профессиональной компетентности методистов профессионально-технических учебных заведений в межкурсовой период повышения квалификаци. 


\title{
Abstract \\ Modern Problems of Professional Competence Development of Methodologists of Vocational Schools in the Period between Courses of Advanced Training
}

\author{
Evdokia Horban, \\ postgraduate student \\ at the Institute of Vocational Education of NAES of Ukraine
}

\section{KEYWORDS:}

vocational education, career guidance, career anchor, career counseling, psychological support career counseling, career competence
The article focuses on the necessity of theoretical substantiation, development and experimental verification of the technology of development of professional competence of methodologists of vocational and technical educational institutions in the intercurrent period of professional development, which includes value-motivational, information-cognitive, professional-activity and reflexive and evaluation stages of implementation, and aims at continuous professional and pedagogical improvement, self-development and self-development, mastering the innovative competencies of a professor ynoyi education, coaching master training and mentoring programs. The controversies arising from the constant introduction of new technology and advanced technologies that require constant readiness of workers for changes in the nature of work and occupations themselves, the growth of general and technical levels, when there objectively arises the need for a comprehensive harmonious development of all actors who take participation in production. Under such conditions, teachers should be prepared to constantly update their knowledge, professional skills and enrich the experience of cognitive practice, supported by relevant value orientations. The structure of pedagogical competence is presented, the essence of professional competence is revealed.

On the basis of generalization of scientific researches it has been established that professional competence is considered as professional training and the ability of pedagogical workers (methodologists) to perform tasks and responsibilities of activity, the measure and the main criterion for their compliance with the requirements of professional activity, which consists of the following components: knowledge, skills, skills professional position, individual psychological peculiarities of man and acmeological factors (values and need for self-development).The focus is on the implementation of the creative potential of methodologists of vocational and technical educational institutions as subjects of professional activity in interaction with other subjects of the educational process through the development of professional competence, which enables them to successfully perform various types of professional activities, to synthesize a wide range of them knowledge and practical actions, reflect the degree of formation of professional culture of specialists and determine the results of their work. The role of methodologists of vocational and technical educational institutions in the organization of scientific and methodological work with pedagogical workers (teachers, masters of industrial training) was characterized. The problems of professional competence development of methodologists of vocational schools in the intercourse period of professional development are revealed.

\section{References}

1. Bielienka H.V. Teoretyko-metodychni zasady formuvannia profesiinoi kompetentnosti vykhovateliv doshkilnykh navchalnykh zakladiv $\mathrm{v}$ umovakh stupenevoi pidhotovky : avtoref. dys. na zdobuttia nauk. stupeniad-ra ped. nauk : spets. 13.00.08 «Teoriia i metodyka profesiinoi osvity» / H.V.Bielienka. - Kyiv, 2012. -38 s.

2. Entsyklopediia osvity / hol. red. akademik NAN i NAPN Ukrainy, Prezydent APN Ukrainy V.H.Kremen. Kyiv, Yurinkom, 2008. - 1036 s.

3. Ziaziun I.A. Pedahohichna maisternist : pidruchnyk / I.A.Ziaziun, I.F.Kravchenko, I.F.Kryvonosa in. ; za red. I.A.Ziaziuna. - 2-he vyd., dopovn. - Kyiv. Vyshcha shkola, 2004. $422 \mathrm{~s}$.

4. Radkevych V.O. Kompetentnisnyi pidkhid do zabezpechennia yakosti profesiinoi osvity i navchannia / V. O. Radkevych - [Elektronnyi resurs]. - http://lib.iitta.gov.ua/

5. Rozvytok informatsiino-analitychnoi kompetentnosti pedahohichnykh pratsivnykiv PTNZ: teoriia i praktyka : monohrafiia / [V. V. Yahupov, N. O. Velychko, I. V. Hyrylovska, A. H. Huraliuk, D. O. Zakatnov, L. A. Maiboroda, V. V. Parzhnytskyi] ; za. nauk. red. V. V. Yahupova. Kyiv : Polihrafservis, 2014. - $176 \mathrm{~s}$.

6. Iahupov V.V. Metodolohycheskye trebovanyia kompetentnosnoho podkhoda $\mathrm{v}$ professyonalnom obrazovanyy / V.V.Yahupov // Vyshcha osvita Ukrainy : teoret. ta naukovometod.chasopys. - 2013. - №13(50). - Dodatok 1 : Pedahohika vyshchoi shkoly: metodolohiia, teoriia, tekhnolohii. - T. 1. - S. 82-85. 